\title{
OPTIMAL HEIGHT OF STEEL PLATE GIRDERS WITH CORRUGATED WEBS
}

\author{
${ }^{1}$ Lavrinenko L.I., $\mathrm{PhD}$, Assistant Professor, \\ ludmila.lavrinenko@gmail.com, ORCID: 0000-0001-5601-0943 \\ ${ }^{1}$ Oleynik D.Y., master, \\ oleynikdaniel18@gmail.com, ORCID:0000-0002-1767-2597 \\ ${ }^{1}$ Kyiv National University of Civil Engineering and Architecture \\ 31, Povitroflotsky Ave., Kyiv, 03037, Ukraine
}

\begin{abstract}
This work is carried out in order to study the classical problem of determining the optimal height of a plate girder with given moment of resistance in relation to the features of the real operation of a beam with a corrugated web. A bi-symmetric plate girder with a wavy web is considered. The structural model parameters of the girder correspond to the Zenam technology, which determines the structural limitations of the task. The physical model is the 1st class double-tee girder according to the stress-strain state (in accordance with the current design standards of Ukraine SCS (State Construction Standards of Ukraine) B.2.6-198). The mathematical model is considered as a task of minimizing the objective function (beam mass) taking into account design factors. The height is a project variable. The objective function is formulated as one-parameter taking into account the bending strength of the beam. The structural coefficients and their influence on the objective function are considered. Both the shear strength constrain and overall wall shape stability constrain are taken into account. Deflections are determined taking into account the shear deformations of the thin web. The minimum values of the beam height are considered when the permissible deflection is not exceeded. It is shown that the introduction of the conditions of shear strength and wall stability into the resolving equation indicates the lower limit of the calculated variable value. The constraint is inactive in the area of feasible solutions.

Areas of rational decisions are shown. Numerical studies have been conducted for corrugated beam structures. Design requirements in accordance with design standards are used as method constraints. The optimal values of the beam height are obtained according to the minimum mass criterion in the range of applied spans and loads. The effective values of spans and loads for beams with corrugated walls in the range of optimal parameters and technological limitations have been determined. Further research is needed to explore constructive solutions that would minimize the values of constructive coefficients, taking into account specific effects such as local tensions and realworld operating conditions.
\end{abstract}

Keywords: steel beam, corrugated web, optimum height, design constraints.

Introduction. It is known that the efficiency of cross sections, as a reduction in steel consumption, increases with decreasing web thickness. As the web thickness decreases, the most important specific cross-sectional characteristics increase - the specific moment of resistance of the section $\bar{W}=W /(A \sqrt{A})$ end the specific radius of inertia $\bar{i}=i \sqrt{A}$, where $A, i, W-$ area, radius of inertia and moment of resistance of the cross section, respectively. This contributes to the creation of elements with high geometric characteristics $W$ and $i$ while reducing the area. Therefore, thinwalled I-beams, cold-formed Z- i C-profiles are widely used. I-beams with a thin web, the flexibility of which $\lambda_{w}=h_{w} / t_{w}$ reaches $400 \ldots 600$, are widely used in load-bearing structures. Thinning of the web is constrained by such factors as the need to perceive the transverse force, to provide stability and to counteract accidental influences, which are often crucial for thin-walled folded I-beams.

The search for ways to obtain a structural shape of thin-walled elements, in which the web with high conditional flexibility $\left(\bar{\lambda}_{\mathrm{w}}>6\right)$ performs its functions without loss of stability, and its manufacture allows the use of highly efficient modern technologies, led to the idea of stiffening thin webs by stamping and corrugation. One of the methods to increase the efficiency of such girders is

Bulletin of Odessa State Academy of Civil Engineering and Architecture, 2020, no. 81, page 76-86 
to determine such dimensions that optimize or streamline their economic performance, especially material consumption.

Analysis of recent research. The paper considers the problem of determining the optimal height of the girder with a corrugated web, which minimizes the mass (or cross-sectional area) of the beam, taking structural coefficients into account. This problem has several practical solutions for many structural forms of beams $[1,2]$, is a classic $[3,4]$ and is to determine the optimal height with a required moment of resistance.

Proximate methods for solving such problems using approximation dependences and empirical coefficients are given in many works [5-7]. Simultaneously with the optimal, the minimum height is taken into account, which is determined under the condition of the maximum allowable deflection of the girder. In this case, for practical use, it is recommended to take the height from the interval between the minimum and optimal.

The tasks of ensuring the optimal cross-sectional dimensions, limiting the structural height by the conditions of operation and installation, taking into account the location of technological equipment in the floor space $[8,9]$, fire protection [10] is relevant. The task of estimating losses at deviation from optimal values of design parameters is important too.

The purpose and objectives of the study. To obtain rational design solutions and the field of effective use of girders with corrugated web in coatings and floors, we need: to investigate the dependence of material consumption on geometric parameters of cross section; to set the optimal value of height as a determining parameter that optimizes girder mass; to appreciate the influence of structural coefficients of the webs and flanges, taking into account the specific features of the corrugated web and the girder as a whole.

Materials and research methods. Constructive model. A symmetrical cross-section I-beam with a wavy sinusoidal corrugated web $t_{w}=2,0 ; 2,5$ and 3,0 $\mathrm{mm}$ thick (assortment profiles WTA-, WTB-, WTC-girder) is considered (Fig. 1). It is possible to make a wall $1.5 \mathrm{~mm}$ thick, as well as increase the thickness to $6 \mathrm{~mm}$ [11]. At the stage of factory production, a sinusoidal profile is formed with a maximum height $f=40 \mathrm{~mm}(f=43 \mathrm{~mm}$ for WTC) and other sinusoidal parameters $m=155 \mathrm{~mm}$, $s=90 \mathrm{~mm}$. In this way, girder with a web height $h_{w}=333,500,625,750,1000,1250$ and $1500 \mathrm{~mm}$ are made. Standard beams are made bi-symmetrical with belts of symmetrical section, width $b_{f}=200 \ldots 450 \mathrm{~mm}$ and $t_{f}=6 \ldots 30 \mathrm{~mm}$ thick. The parameters of the flanges are also determined by the capabilities of the equipment $[12,13]$.

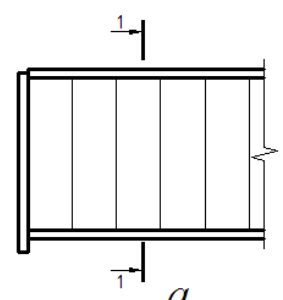

a
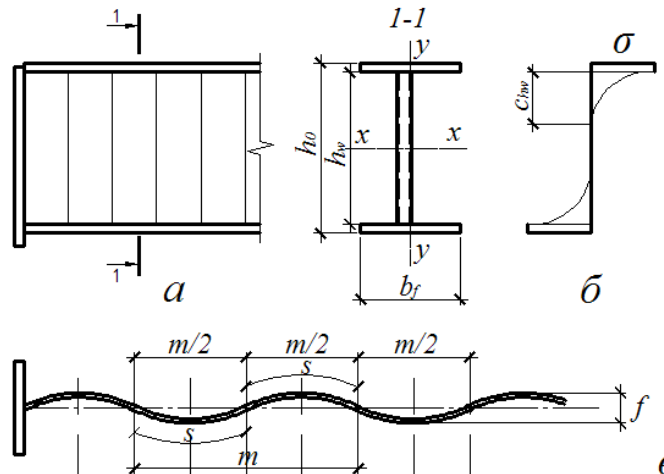

b
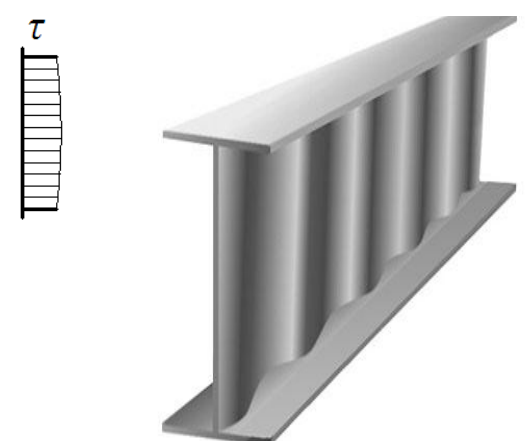

Fig. 1. Constructive decision of a beam and designations:

$a$ - the general view; $\sigma$ - the diagrams of normal and tangential stresses; $b-$ the geometry of the corrugated web

The girder calculation scheme is a single-span beam with span $l$ and vertical loading $q$, located in the average plane of a web. Flanges of girder are accepted constant section on length, local stability of flanges is achieved using standard values of dimensional ratio of the flanges $\lambda_{f} \approx b_{f 0} / t_{f}$; 
$\bar{\lambda}_{u f} \geq \bar{\lambda}_{f} \approx \lambda_{f} \sqrt{R_{y} / E}$. The overall stability of the girder is considered to be ensured. Outside the plane the beam is supported by secondary beams or flooring, a system of ties, etc.

Additional details are taken into account through structural coefficients [14]. The structural coefficient $\psi_{C}$ is defined as the ratio of the total mass of the main and additional elements and details of the structure $m_{C}=m_{0}+\sum m_{i r}$ to the theoretical mass of the main structural elements, $m_{0}$. In the same way the structural coefficients for the web $\psi_{p w}$ and flanges $\psi_{p f}$ are determined :

$$
\begin{gathered}
\psi_{C}=\frac{m_{0}+\sum m_{i r}}{m_{0}}=\frac{m_{C}}{m_{0}}, \quad \text { де } m_{b C}=m_{0}+\sum m_{i r}, \\
\psi_{p \omega}=\frac{m_{\omega 0}+\sum m_{i r \omega}}{m_{\omega 0}} ; \\
\psi_{p f}=\frac{m_{f 0}+\sum m_{i r f}}{m_{f 0}}, \text { або } \psi_{p f}=1+\frac{\sum m_{i r f}}{m_{f 0}} .
\end{gathered}
$$

The web structural coefficient $\psi_{p w}$ takes into account the structural design of the web; the structural coefficient of the flanges $\psi_{p f}$ takes into account the design features of the beam in the composition of the coating or floor.

Physical-mechanical model of the girder is a 1st class double-tee girder according to the stressstrain state (in accordance with the current design standards of the Ukrainian SCS B.2.6-198). The elastic operation of the beam in general allows the appearance of limited plastic deformations, which go beyond proportionality with the loss of local stability of the flange and web [15]. Features of work of beams with cross-corrugated webs are considered further based on the methodical receptions developed at the Kyiv National University of Civil Engineering and Architecture [16].

The web perceives normal stresses only in a narrow zone of height $c h_{w}$ directly near the flanges (Fig. $1, b$ ). In girders with high conditional web flexibility $\bar{\lambda}_{w}>6$ the effect of this zone on the loadbearing capacity is insignificant and is usually neglected. In this case, only the flanges perceive the bending moment, and the diagram of shear stresses in the web is close to rectangular:

$$
\begin{gathered}
\sigma=\frac{M}{h_{0} A_{f n}} \leq R_{y f} \gamma_{c}, \\
\tau_{x y}=\frac{Q}{h_{w} t_{w}} \leq R_{s w} k_{s} \gamma_{c},
\end{gathered}
$$

where $M$ - the bending moment from the calculated ultimate load; $h_{0}$ - the distance between the centers of gravity of the flanges; $A_{f}$ - net cross-sectional area of the flange; $\gamma_{c}$ - coefficient of operating conditions of the element (SCS B.2.6-198); $R_{y f}$ - the calculated resistance of the steel flanges; $R_{s w}-$ the calculated shear resistance of the steel web; $k_{s}$ - coefficient depending on the flexibility of the thin corrugated web $\overline{\lambda_{w}}=\frac{h_{w}}{t_{w}} \sqrt{\frac{R_{y w}}{E}}$ and takes into account its geometrically nonlinear behavior:

$$
k_{s}=1,085-0,08 \overline{\lambda_{w}} \leq 1,0 .
$$

The mathematical model is considered as the task of minimizing the objective function - the mass of the girder taking into account the structural coefficients. In general, it can be formed as a nonlinear programming problem with the inequality constraints on bending strength, shear strength, general and local web stability, and deflections too [17]. When separating incompatible or contradictory constraints into a separate group, following the peculiarities of the stress-strain state of the girder, and replacing the remaining constraints with equality, the problem as a whole is greatly simplified. 
It is assumed that the flanges are thin compared to the height of the girder $h_{0}$ and are characterized by one parameter $A_{f}$ - the cross-sectional area of the flange. The web is characterized by two parameters - height $h_{w} \approx h_{0}$ and thickness $t_{w}$. Geometric characteristics of the cross section of the I-girder are expressed by the formulas:

$$
A_{0}=2 A_{f}+t_{w} h_{w}, I_{0}=\frac{h_{0}^{2}}{4}\left(\frac{1}{c_{f}} \cdot 2 A_{f}+\frac{1}{c_{w}} \cdot \frac{t_{w} h_{w}}{3}\right), W_{0}=\frac{h_{0}}{2}\left(\frac{1}{c_{f}} \cdot 2 A_{f}+\frac{1}{c_{w}} \cdot \frac{t_{w} h_{w}}{3}\right), A_{w}=t_{w} h_{w},
$$

where $A$ - cross-sectional area, $I-$ the moment of inertia of the cross-section relative to the $x-x$ axis, $W$ - the moment of resistance of the cross-section relative to the $x-x$ axis, $A_{w}-$ the crosssectional area of the web.

Previous studies [1] when considering bending elements involve determining the proportion of bending moment on the shelf and wall:

$$
c_{f}=M_{f} / M_{0}, \quad c_{w}=1-c_{f} .
$$

For girders with cross-corrugated webs, the values of the distribution coefficient can be taken $c_{f}=1.0[13,16]$.

Presentation of the main material. 1. Formation of the objective function with bending strength constrains for the girder. The challenge is to minimize the girder mass function with project variable $h_{0}$ :

$$
m_{b C}=m_{f}+m_{w}=\rho l\left(2 \psi_{p f} A_{f}+\psi_{p w} t_{w} h_{0}\right)
$$

Normal stress strength condition in $(2, a)$ :

$$
W_{0}=W_{w}+W_{f}=k_{R} \frac{M_{0}}{R_{y f} \gamma_{c}}
$$

here $k_{R}$ - the factor for determining the force depending on the calculation scheme of the beam.

Take (4) and write for a corrugated web with $W_{w}=0$ :

$$
A_{f}=c_{f} \frac{W_{x}}{h_{0}}=c_{f} \cdot k_{R} \cdot \frac{M_{0}}{R_{y} \gamma_{c} \cdot h_{o}} .
$$

The mass function of the beam takes on the form and changes with the substitution of a given (required) moment of resistance $M_{0} / R_{y} \gamma_{c}=W_{c a l}$ :

$$
m_{b C}=2 \rho \psi_{p f} \cdot c_{f} \cdot k_{R} \cdot \frac{M_{0}}{R_{y} \gamma_{c}} \cdot \frac{l}{h_{o}}+\rho \psi_{p w} t_{w} h_{0} l==2 \rho \psi_{p f} \cdot c_{f} \cdot k_{R} \cdot W_{c a l} \cdot \frac{l}{h_{o}}+\rho \psi_{p w} t_{w} h_{0} l .
$$

We obtain the minimum of the function provided that the first derivative with respect to the project variable $h_{0}$ is equal to zero $m_{b C}^{\prime}=0$ :

$$
m_{b C}^{\prime}=-2 \psi_{p f} \cdot c_{f} \cdot k_{R} \cdot W_{c a l} \cdot \frac{l}{h_{o}^{2}}+\psi_{p w} t_{w}=0
$$

From the solution of equation (8) we obtain the optimal value of the beam height that minimizes steel consumption:

$$
\begin{gathered}
h_{0}=\sqrt{\frac{2 \psi_{p f} c_{f}}{\psi_{p w}}} \cdot \sqrt{\frac{k_{R} W_{c a l}}{t_{w}}}, \\
\text { and also after replacement } \sqrt{\frac{2 \psi_{p f} c_{f}}{\psi_{p w}}}=\sqrt{k_{q}}=k_{t}: \\
h_{0}=k_{t} \cdot \sqrt{\frac{k_{R} W_{c a l}}{t_{w}}} .
\end{gathered}
$$


Similarly, the optimal girder height was obtained using the value of wall flexibility $\lambda_{w}=h_{0} / t_{w}:$

$$
h_{0}=\sqrt[3]{k_{q}} \cdot \sqrt[3]{k_{R} W_{c a l} \cdot \lambda_{w}}=k_{\lambda} \sqrt[3]{k_{R} W_{c a l} \cdot \lambda_{w}}
$$

The structural coefficient of the flange $\psi_{p f} \geq 1.0$ takes into account additional constructive details of a girder for its operation as a part of a covering or a floor (details for fixing of beams, floorings, etc.). The structural coefficient of the web takes into account the increase in steel during corrugation compared with a plate web of the same thickness, and also the material on the end (support) and intermediate (mounting) ribs, etc. Its least value:

$$
\psi_{p w, 0} \geq \frac{2 s}{m}=\frac{2 \cdot 90}{155}=1,161 .
$$

Analysis of structural coefficients influence on the calculated coefficients allows to actualize the design features of beams with wavy corrugated webs (Table 1).

Table 1 - The calculated coefficients $k_{t}$ and $k_{\lambda}$

\begin{tabular}{|c|c|c|c|c|}
\hline \multicolumn{2}{|c|}{ The values of structural coefficients } & \multirow{2}{*}{$k_{q}$} & \multirow{2}{*}{$k_{t}=\sqrt{k_{q}}$} & $k_{\lambda}=\sqrt[3]{k_{q}}$ \\
\hline$\psi_{p w}$ & $\psi_{p f}$ & & & \\
\hline 1,161 & 1,0 & 1,723 & 1,313 & 1,199 \\
\hline 1,25 & 1,05 & 1,680 & 1,296 & 1,189 \\
\hline 1,30 & 1,05 & 1,615 & 1,271 & 1,173 \\
\hline 1,40 & 1,05 & 1,500 & 1,225 & 1,145 \\
\hline
\end{tabular}

2. Shear strength constraint. The obtained dependences do not give grounds to assert that the wall has reached the limiting state. Given the type of objective function (5), it can be argued that reaching the tensile strength at normal stresses (in the flanges) and tangential stresses (in the web) is not required simultaneously in the same cross section.

The web thickness along the length of the girder is considered constant. In the girder of the optimal height, when the strength by shear stresses in the web is exhausted, we can obtain the lower values of height. This can be written as an additional limitation-equation $(2, b)$. Based on it, the required web thickness is:

$$
t_{w}=\frac{Q}{k_{s} R_{s} \gamma_{c} h_{0}}
$$

which can be taken into account in the objective function (7) and be included in the equation (8):

$$
-k_{q} \frac{k_{R} W_{c a l}}{h_{0}^{2}}+\frac{Q}{k_{s} R_{s} \gamma_{c} h_{0}}=0 .
$$

When the load-bearing capacity is completely exhausted, the ratio of the loading parameters is $W c a l / Q=l / \xi R_{y} \gamma_{c}$. This modifies the formula for the optimal beam height. At $W_{c a l}=M / R_{y} \gamma_{c}$, after obvious transformations, the formula has the form:

$$
h_{0 s}=k_{q} \frac{k_{R} W_{c a l} R_{s} \gamma_{c}}{Q}=k_{q} k_{R} \frac{l}{\xi} 0,58 R_{y}
$$

Here, a coefficient $\xi=Q l / M$ is introduced to simplify the analysis, it acquires known values. For example, for a single-span beam with span $l$ and distributed load $q$ the calculated effort is equal $M=q l^{2} / 8, Q=q l / 2, \xi=4$; for concentrated loads placed in $1 / 3$ of the span $M=P l / 3$, $Q=P, \xi=3$ etc. 
With the introduction of equality constraints in the resolving equation (11), we obtain the value of the lower limit of the design variable. The constraint is also not decisive due to the fact that it is theoretically impossible to load the web to the ultimate shear strength simultaneously with taking into account other factors of the stress-strain state $[15,18]$.

3. Web stability constraints. When designing a girder, it is necessary to be convinced that the constraint "from above" connected with a condition of stability of a corrugated web is carried out. For girders at $\beta=h_{w} / 0,5 m \geq 8,4$ the decisive factor is the general loss of web stability associated with the buckling of the web in the area of several corrugations. In this case, the tangential critical stresses of the total loss of stability for the corrugated web according to the current design standards DBN B.2.6-198 and research $[13,16]$ are:

$$
\tau_{p, c r}=32,4 \frac{\sqrt[4]{D_{1} D_{2}^{3}}}{h_{w}^{2} t_{w}}, \quad D_{1}=\frac{E t_{w}^{3}}{12\left(1-v^{2}\right)} \cdot \frac{m}{2 s}, \quad D_{2}=\frac{E I}{m} .
$$

If the geometry of the wall is described by the equation $y(x)=\frac{f}{2} \sin \left(\frac{\pi x}{m / 2}\right)$, then the bending stiffness of an orthotropic plate in the main directions for the web $D_{1}$ and $D_{2}$ are determined depending on the moments of inertia of a single wave relative to the longitudinal axis (Table 2).

Table 2 - Wavy web parameters

\begin{tabular}{|c|c|c|c|}
\hline \multirow{2}{*}{ Web parameters } & \multicolumn{3}{|c|}{ Profile type } \\
\cline { 2 - 4 } & WTA & WTB & WTC \\
\hline$I, \mathrm{~cm}^{2}$ & 6,674 & 8,343 & 10,012 \\
\hline$k_{\tau} \cdot 10^{-4}$ & 27,458 & 30,702 & 33,632 \\
\hline
\end{tabular}

After all the transformations and substitutions:

$$
\tau_{p, c r}=\frac{32,4}{h_{0}^{2}} \cdot \sqrt[4]{\frac{E^{4} I^{3}}{24 s m^{2} t_{w}}}=\frac{k_{\tau}}{h_{0}^{2}}, \text { here } k_{\tau}=32,4 E \cdot \sqrt[4]{\frac{I^{3}}{24 s m^{2} t_{w}}} .
$$

The web stability condition allows us to write:

$$
\frac{\tau}{\tau_{c r}}=1, \quad \text { if } \frac{Q}{h_{0} t_{w}}=\frac{k_{\tau}}{h_{0}^{2}}, \text { then } t_{w}=\frac{Q h_{0}}{k_{\tau}} .
$$

The numerical values for the corrugated parameter (coefficient $k_{\tau}$ ) are in the Table. 2.

Thus, if the depletion of the bearing capacity is obtained both in terms of strength and overall stability of the corrugated wall, then the objective function (7) and the condition of ensuring the minimum beam mass (8) takes the form:

$$
-k_{q} \frac{k_{R} W_{c a l}}{h_{0}^{2}}+\frac{Q h_{0}}{k_{\tau}}=0
$$

The optimal height value for this case:

$$
h_{0 \tau}=\sqrt[3]{k_{q}} \cdot \sqrt[3]{k_{R} k_{\tau} \frac{W_{c a l}}{Q}}=k_{\lambda} \cdot \sqrt[3]{\frac{l}{\xi R_{y} \gamma_{c}} k_{R} k_{\tau}} .
$$

The remarks concerning the introduction of the equality constrain in the solution equation (16) are the same as concerning (11). The constrain is not active and provides the upper limit value of the design variable.

4. The structural limitation is to take into account the technological capabilities of the equipment in the manufacture of corrugated webs:

$$
h_{0} \approx h_{w} \leq 1500 \mathrm{~mm} \text {. }
$$


5. The deflection constraint (check). Additionally, the deflection constraint can be introduced. Due to the presence of a thin web, the influence of shear deformations is significant, the share of which in the total deviation reaches $(25 \ldots 30) \%$. In the case of distributed load, the maximum deviation is:

$$
f=\frac{5 M_{e} l^{2}}{48 E I_{f}}+\frac{Q_{e} l}{G_{r e d} A_{w}} \leq f_{u},
$$

where $M_{e}$ and $Q_{e}$ - calculated effort for the second limit state, $I_{f}=A_{f} h_{0}^{2} / 2$ - the cross section moment of inertia for the beam, calculated without the web area; $G_{r e d}=G \frac{m}{2 s}$ - the calculated shear modulus taking into account the increased deformability of the corrugated web.

If the limiting state in strength is reached simultaneously by both the wall and the shelf, then $M=W R_{y} \gamma_{c}, Q=t_{w} h_{w} R_{y} \gamma_{c}$, for this $I / W=h / 2$, and we can write:

$$
h_{\min }=\frac{5}{24} \cdot \frac{R_{y} \gamma_{c}}{E} \cdot \frac{l}{\left[\left(\frac{f}{l}\right)_{u}-\frac{R_{s} \gamma_{c}}{G_{r e d}}\right]} \cdot \frac{1}{\gamma_{\text {fm,mean }}} .
$$

The value obtained by expression (20) is excessive, because it uses the condition of complete exhaustion of the strength of both the wall and the shelves at the same time. Therefore, as a test should use a formula that contains the actual value of the cutting force and does not imply the inevitable achievement of the wall shear strength:

$$
h_{\min }=\left(\frac{5}{24} \cdot \frac{R_{y} \gamma_{c} l}{E}+\frac{Q}{G_{r e d} t_{w}}\right) \frac{1}{\left(\frac{f}{l}\right)_{u}} \cdot \frac{1}{\gamma_{f m, \text { mean }}} .
$$

In (20) and (21) $\gamma_{f m, m e a n}$ - the mean coefficient for the transition from the design load of the 1 st limit state to the loads of the 2 nd limit state, $(f / l)_{u}$ - relative limit deflection according to Ukrainian standard DSTU MT.1.2-3 «Deflections and displacements».

6. The numerical research. The following example considers this calculation situation (Fig. 2 and Fig. 3): girder span $\mathrm{L}=18 \mathrm{~m}$, own weight load $1.2 \mathrm{kN} / \mathrm{m}^{2}$, snow load $1,5 \mathrm{kN} / \mathrm{m}^{2}$, spacing of girders $B=6 \mathrm{~m}$, design solution is corrugated girder WTA, steel grade C255.

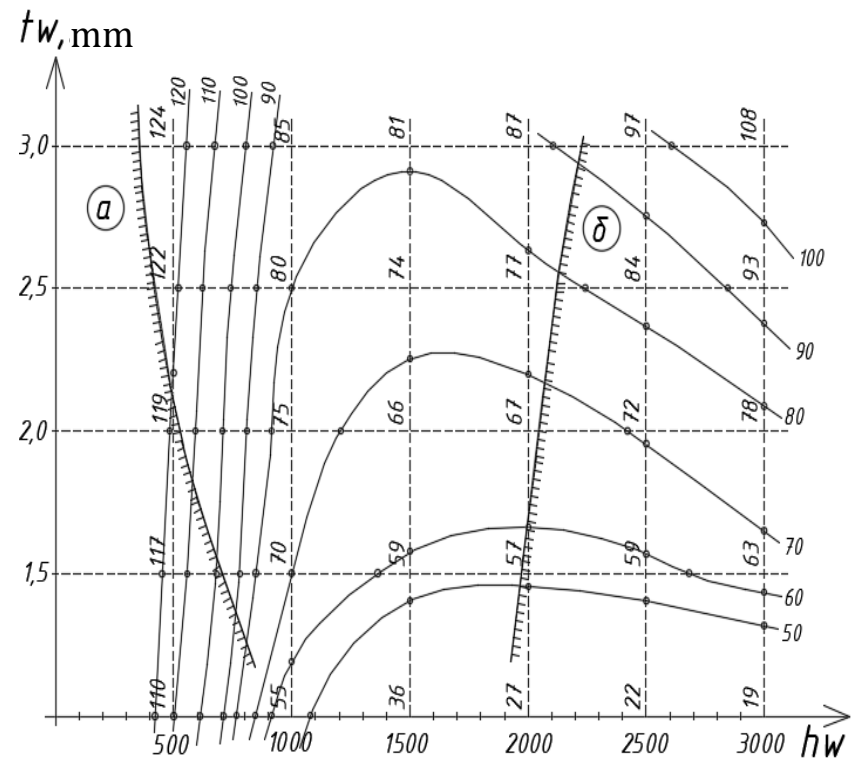

Fig. 2. Numerical study of the objective function (5) (according to the example). Objective function levels lines (isolines): $a$ - the strength constraint of the web; $b$ - the web stability constraint

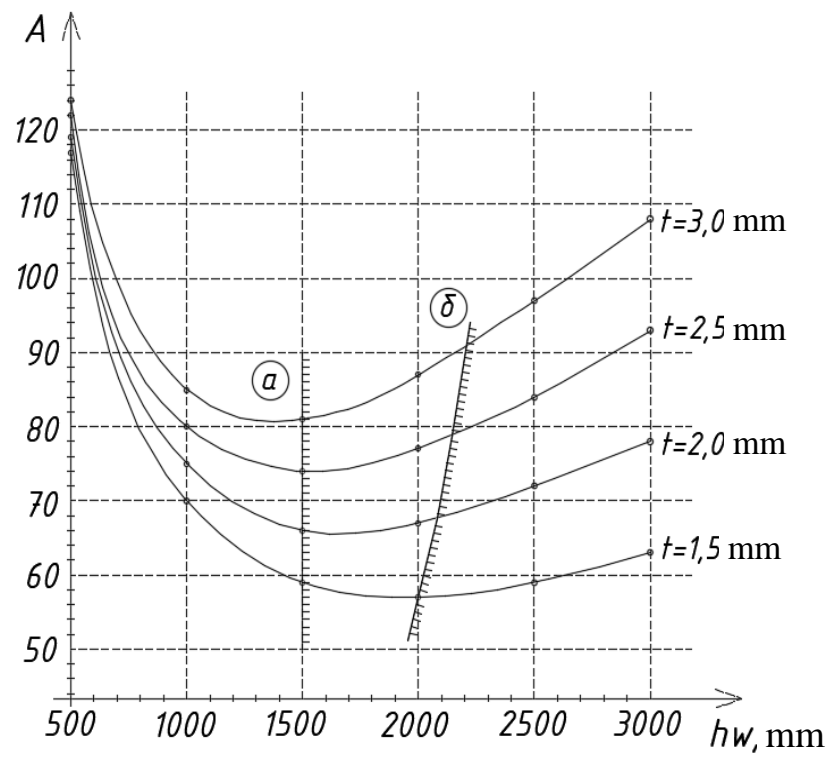

Fig. 3. Function $\mathrm{A}=2 \psi_{p f} A_{f}+\psi_{p w} t_{w} h_{0}$ (5) with constraints (according to the example): $a$ - the structural limitation $b$ - the web stability constraint 
Determined that $W_{\text {cal }}=2734 \mathrm{sm}^{3}$ and $Q=146 \mathrm{kN}$, the height is optimal for $(9, \mathrm{~b})$, with taking into account the constraints (12) and (17) are: $h_{o p t}=153 \mathrm{sm}, h_{0 s}=107.9 \mathrm{sm}, h_{0 \tau}=207 \mathrm{sm}$. The minimum height is determined provided that the permissible deviation $f_{u} \leq(1 / 250) l$ is not exceeded: $h_{\min }=114 \mathrm{sm}$. The obtained values are limited by the value (18), the final height of the wall is $1500 \mathrm{~mm}$.

This example can be illustrated graphically (Fig. 2) by levels lines (isolines) of the objective function - the mass of the beam $m_{b C}(5)$. Isolines are shown on a two-dimensional plane in coordinates $h_{w}$ (web height) $-t_{w}$ (web thickness). The objective function for thin webs has a smooth minimum (Fig. 3), which indicates its low sensitivity in the field of optimal solutions.

Research results. The given illustration confirms the obtained numerical results and makes it possible to trace the formation dependences of the rational cross-sections of beams with wavy cross-corrugated webs. The imperfection of the solution is the fact that real design solutions have discrete values of design parameters. However, the investigated function (5) has a gentle minimum (Fig. 3), where the assortment discreteness and the deviation of height from the optimal values by $(10 \ldots 15) \%$ does not lead to large losses relative to the optimal values of mass.

The range of allowable solutions of optimal beams is significantly limited by the structural limitation (18). The limit linear load values for the optimal beams with wavy webs depending on the spans shows in the table. 3. Such linear loads for real buildings are achieved at spans up to $18 \mathrm{~m}$ and crossbar step $6 \ldots 8 \mathrm{~m}$, and up to $24 \mathrm{~m}$ at a step $3 \ldots 4 \mathrm{~m}$. For real buildings, such linear loads are considered for spans up to $18 \mathrm{~m}$ and spacing of girders $6 \ldots 8 \mathrm{~m}$, and up to $24 \mathrm{~m}$ at a step $3 \ldots 4 \mathrm{~m}$. The optimal height of the girders for large spans exceeds $1500 \mathrm{~mm}$. When designing such girders up to $1500 \mathrm{~mm}$ high, they are not optimal or require special design solutions, which are not considered here.

Table 3 - Areas of admissible solutions for optimal girders at $h_{w}=1500 \mathrm{~mm}, R_{y}=270 \mathrm{~N} / \mathrm{mm}^{2}$

\begin{tabular}{|c|c|c|c|c|c|c|c|c|}
\hline \multicolumn{9}{|c|}{ A. The optimal girders due to bending strength } \\
\hline \multirow{2}{*}{$\begin{array}{c}t_{w} \\
(\mathrm{~mm})\end{array}$} & \multirow{2}{*}{$\begin{array}{c}M_{u} \\
(\mathrm{kNm})\end{array}$} & \multicolumn{7}{|c|}{ Maximum linear load $q(\mathrm{kN} / \mathrm{m})$ for spans $l(\mathrm{~m})$} \\
\hline & & 6 & 12 & 18 & 24 & 30 & 36 & 42 \\
\hline 1.5 & 528.58 & 117.44 & 29.39 & 13.05 & 7.34 & 4.70 & 3.28 & 2.40 \\
\hline 2.0 & 704.77 & 156.62 & 38.15 & 17.40 & 9.79 & 6.26 & 4.35 & 3.20 \\
\hline 2.5 & 880.96 & 195.77 & 48.94 & 21.75 & 12.24 & 7.83 & 5.44 & 4.00 \\
\hline 3.0 & 1057.15 & 234.90 & 58.73 & 26.10 & 14.68 & 9.40 & 6.53 & 4.79 \\
\hline \multicolumn{9}{|c|}{ B. Shear strength constraint } \\
\hline \multirow{2}{*}{$\begin{array}{c}t_{w} \\
(\mathrm{~mm})\end{array}$} & \multirow{2}{*}{$\begin{array}{c}Q_{u} \\
(\mathrm{kNm})\end{array}$} & \multicolumn{7}{|c|}{ Maximum linear load $q(\mathrm{kN} / \mathrm{m})$ for spans $l(\mathrm{~m})$} \\
\hline & & 6 & 12 & 18 & 24 & 30 & 36 & 42 \\
\hline 1.5 & 352.35 & 117.44 & 58.72 & 39.15 & 29.36 & 23.49 & 19.58 & 16.78 \\
\hline 2.0 & 469.80 & 156.60 & 78.30 & 50.50 & 39.15 & 31.32 & 25.25 & 22.37 \\
\hline 2.5 & 587.25 & 195.75 & 97.87 & 65.25 & 48.94 & 39.15 & 32.63 & 27.97 \\
\hline 3.0 & 704.70 & 234.90 & 117.44 & 78.30 & 58.72 & 46.98 & 39.15 & 33.56 \\
\hline \multicolumn{9}{|c|}{ C. Web stability constraints } \\
\hline \multirow{2}{*}{$\begin{array}{c}t_{w} \\
(\mathrm{~mm})\end{array}$} & \multirow{2}{*}{$\begin{array}{c}Q_{u} \\
(\mathrm{kNm})\end{array}$} & \multicolumn{7}{|c|}{ Maximum linear load $q(\mathrm{kN} / \mathrm{m})$ for spans $l(\mathrm{~m})$} \\
\hline & & 6 & 12 & 18 & 24 & 30 & 36 & 42 \\
\hline 1.5 & 237.9 & 79.3 & 39.65 & 26.43 & 19.83 & 15.86 & 13.22 & 11.33 \\
\hline 2.0 & 366.11 & 122.04 & 61.02 & 40.68 & 30.51 & 24.41 & 20.34 & 17.43 \\
\hline 2.5 & 511.70 & 170.56 & 85.28 & 56.86 & 42.64 & 34.11 & 28.43 & 24.37 \\
\hline 3.0 & 672.65 & 224.20 & 112.10 & 74.74 & 56.05 & 46.09 & 37.37 & 32.03 \\
\hline
\end{tabular}




\section{Conclusions and prospects for further research:}

1. It is shown that some geometrical parameters of the girder with a transverse corrugated web can be determined as optimal taking into account the specific features of the girder. For a bisymmetric cross section, the simplest criterion is the minimum mass under the condition of the normal stresses strength, shear stress constraint, corrugated web stability and structural constraints. The analysis of structural coefficients of a web and flanges is carried out.

2. The classic problem is discussed considering the work of the corrugated web in the girder. The known solution is specified [16]. The problem is compounded by shear strength constraints and web stability constraints. Deformation constraints are more fully taken into account. Constraints are not active and are used to limit the scope of the considered parameters.

3. The dependences obtained in the work help to analyze the geometric parameters of the optimal girders, identify areas of effective solutions and establish rational design solutions for coatings and floors using girders with corrugated webs [8].

4. Clarification of the influence of constructive coefficients is possible in parallel with the analysis of such constructive decisions that lead to a decrease in these coefficients. Such solutions include unloading the web in order to eliminate local transverse stresses and transfer loads from adjacent structures without including the web in the work $[8,18]$.

5. Further research should be performed taking into account the specific effects of corrugated girders, such as local stresses in the web when applying a load on a limited area of the flange, refining the coefficients of the method taking into account imperfections and real operating conditions, etc. $[19,20]$.

\section{References}

[1] S.I. Bilyk, N. Aied Altaie, L.I. Lavrinenko, "Konstruktyvni koefitsiienty ta ratsionalna vysota stalevoi korobchastoi balky postiinoho pererizu", Budivelne vyrobnytstvo: Vidomchyi naukovo-tekhnichnyi zbirnyk (tekhnichni nauky), no. 62/1, pp. 33-38, 2017.

[2] S.I. Bilyk, "Metodyka vyznachennia optymalnoi vysoty ctalevoi dvotavrovoi balky zi zminnym pererizom stinky pry rozvytku obmezhenykh plastychnykh deformatsii", $Z b$. nauk. prats Ukrainskoho instytutu stalevykh konstruktsii im. V.M. Shymanovskoho, vol. 9, pp. 28-33, 2012.

[3] V.N. Hordeev, "Elementarnie zadachy optymyzatsyy dvutavra", Zb. nauk. prats Urainskoho naukovo-doslidnoho ta proektnoho instytutu stalevykh konstruktsii imeni V.M. Shymanovskoho, vol. 3, pp. 27-48, 2009.

[4] V.M. Vakhurkyn, "Forma dvutavrovoi balky v uslovyiakh naymensheho raskhoda metalla y v uslovyiakh naymenshei stoymosty", Vestnyk ynzhenerov y tekhnyk, no. 5, pp. 213-219, 1951.

[5] V.V. Byriulev, Y.Y. Koshyn, Y.Y Krylov, A.V. Sylvestrov, Proektyrovanye metallycheskykh konstruktsyi. Spetskurs, L., Stroiyzdat, 1990.

[6] V.A. Permiakov, A.V. Perelmuter, V.V. Yurchenko, Optymalnoe proektyrovanye stalnikh sterzhnevikh konstruktsyi, K., Stal, 2008.

[7] S. Bilyk, V. Tonkacheiev, "Determining sloped load limits inside von mises' truss with elastic support", Journal Materiali in tehn, vol. 52, no. 2, pp. 105-110, 2018.

[8] A.S. Shyshkyn, L.Y. Lavrinenko, "Effektyvnost komponovochnikh skhem balochnыkh pokrityi y perekrityi na osnove balok s hofryrovannoi stenkoi dlia uslovyi Turkmenystana", Mistobuduvannia ta terytorialne planuvannia, vol. 59, pp. 485-493, 2016.

[9] L.I. Lavrinenko, H.V. Hetun, T.A. Nilova, "Zastosuvannia balok z hofrovanymy stinkamy pry rekonstruktsii ta pidsylenni perekryttiv", Ekspluatatsiia ta rekonstruktsiia budivel $i$ sporud: III Mizhnarodna naukovo-praktychna konferentsiia. Odes'ka derzhavna akademiia budivnytstva ta arkhitektury, 2019, p. 92.

[10] L.I. Lavrinenko, V.S. Nekora, "Doslidzhennia nahrivannia stalevoi balky z hofrovanoiu stinkoiu v umovakh pozhezhi", Budivelni konstruktsii. Teoriia i praktyka, vol. 6, pp.12-21, 2020. doi.org/10.32347/2522-4182.6.2020.12-21. 
[11] H. Pasternak, J. Robra, V. Bachmann, "Corrugated web beams with increased web thickness", Proceedings 5thEuropea Conference on Steel and Composite Structures. Graz, Austria, pp. 1161-1166, 2008.

[12] W. Siokola, "Wellstegträger. Herstellung und Anwendung von Trägern mit profiliertem", Steg, Stahlbau, no. 66, pp. 595 - 605, 1997.

[13] B. Johansson, R. Maquoi, G. Seldasek, C. Muller, D. Beg, "Commentary and worked examples to EN 1993-1-5 Plated Structural Elements", JRS Scientific and Technical Reports, pp. 152-167, 2007.

[14] Y.M. Lykhtarnykov, Varyantnoe proektyrovanye y optymyzatsyia stalnykh konstruktsyi, M., Stroiyzdat, 1979.

[15] O.O. Nilov, L.I. Lavrinenko, T.O. Nilova, "Mistseva stiikist elementiv pererizu stalevykh balok z poperechno hofrovanymy stinkamy v oblasti pruzhno-plastychnoi roboty", $Z b$. nauk. prats Ukrainskoho instytutu stalevykh konstruktsii im. V.M. Shymanovskoho, vol. 18, pp. 33-50, 2016.

[16] O.O. Nilov, T.O. Nilova, Metalevi konstruktsii. Balky. Kolony: Navchalnyi posibnyk, K., Lohos, 240 p.

[17] D. Himmelblau, Prykladnoe nelyneinoe prohrammyrovanye, M., Myr, 1975.

[18] Vuzol spriazhennia stalevykh balok z poperechno hofrovanymy khvyliastymy stinkamy: Patent na korysnu model UA: MPK E04S3/07 (2006.01). №120477; zaiavl. 01.03.2017, publ. 10.11.2017, Biul. no. 21, 4 p., 2017.

[19] L.I. Lavrinenko, A.S. Zotina, "Efektyvni parametry maloelementnyh shprengelnyh ferm iz zastosuvanniam dvotavrovyh elementyv z gofrovanimy stinkamy", Budivelni konstruktsii. Teoriia i praktyka, vol. 4, pp. 56-59, 2020. doi.org/10.32347/2522-4182.4.2019.56-69.

[20] S.I. Bilyk, T.O. Nilova, I.Y. Semchuk, L.I. Lavrinenko, "Experimental and Theoretical Investigation of Inserted Floors with Decreased Height", Varilna Tehnika, vol. 69, pp. 7$15,2019$.

\title{
ОПТИМАЛЬНА ВИСОТА СТАЛЕВИХ БАЛОК З ПОПЕРЕЧНО ГОФРОВАНИМИ СТІНКАМИ
}

\author{
${ }^{1}$ Лавріненко Л.І., к.Т.н., доцент, \\ ludmila.lavrinenko@gmail.com, ORCID: 0000-0001-5601-0943 \\ ${ }^{1}$ Олійник Д.Ю., магістр, \\ oleynikdaniel18@gmail.com, ORCID: 0000-0002-1767-2597 \\ ${ }^{1}$ Київський національний університет будівництва і архітектури \\ пр. Повітрофлотський, 31, м. Київ, 03037, Україна
}

Анотація. В статті розглядається класична задача визначення оптимальної висоти складеної балки із заданим моментом опору з урахуванням особливостей дійсної роботи бісиметричної балки з хвилястою стінкою. Параметри конструктивної моделі балки прийняті стосовно технології Zenam, что накладає на задачу конструктивні обмеження. Фізична модель - балка двотаврового перерізу 1 класу за напружено-деформованим станом (у відповідності до ДБН В.2.6-198). Математична модель побудована як задача мінімізації цільової функції (маси балки з урахуванням конструктивних коефіцієнтів) за висотою як параметром проектування. Функція цілі сформульована як однопараметрична з урахуванням обмеження за міцністю балки при згині. Розглянуті конструктивні коефіцієнти та їх вплив на функцію цілі. Враховані обмеження за міцністю стінки на зріз та втратою стійкості стінки за загальною формою. Показано, що при введенні в розв'язувальне рівняння умов міцності на зсув та стійкість стінки, отримані рішення вказують на нижню межу значень параметру проектування. Обмеження неактивне в області допустимих рішень. Розглянуто також значення мінімальної висоти за умовою неперевищення допустимого прогину з урахуванням деформації зсуву тонкої стінки. 
Показані області раціональних рішень. Проведені чисельні дослідження. для балкових конструкцій з хвилястою стінкою, як обмеження використовуються нерівності/рівності умов забезпечення несучої спроможності відповідно до ДБН В.2.6-198. Отримані оптимальні значення висоти балки за критерієм мінімуму маси в діапазоні використовуваних прольотів та навантажень. Наведені значення прольотів та навантажень для балок з хвилястими стінками в області оптимальних параметрів та технологічних обмежень.

Відмічається необхідність проведення подальших досліджень 3 метою пошуку конструктивних рішень, що знижують значення конструктивних коефіцієнтів, а також з детальним урахуванням таких специфічних ефектів роботи гофрованих балок, як локальні напруження, недосконалості та реальні умови експлуатації

Ключові слова: сталева балка, гофрована стінка, оптимальна висота, обмеження проектування.

\title{
ОПТИМАЛЬНАЯ ВЫСОТА СТАЛЬНЫХ БАЛОК С ПОПЕРЕЧНО ГОФРИРОВАННОЙ СТЕНКОЙ
}

\author{
${ }^{1}$ Лавриненко Л.И., к.т.н., доцент, \\ ludmila.lavrinenko@gmail.com, ORCID: 0000-0001-5601-0943 \\ 'Олийнык Д.Ю., магистр, \\ oleynikdaniel18@gmail.com, ORCID: 0000-0002-1767-2597 \\ ${ }^{1}$ Киевский национальный университет строительства и архитектуры \\ Воздухофлотский пр. 31, г. Киев, 03037, Украина
}

\begin{abstract}
Аннотация. В статье рассматривается классическая задача определения оптимальной высоты составной балки с заданным моментом сопротивления с учетом особенностей работы бисимметричной балки с волнистой стенкой. Параметры конструктивной модели балки соответствуют технологии Zenam, что определяет конструктивное ограничение задачи. Физическая модель - балка двутаврового сечения 1 класса по напряженно-деформированному состоянию (в соответствии с ДБН В.2.6-198). Математическая модель построена как задача минимизации целевой функции (массы балки) с учетом конструктивных коэффициентов по высоте как параметру проектирования. Функция цели сформулирована как однопараметрическая с учетом ограничения по прочности балки при изгибе. Рассмотрены конструктивные коэффициенты и их влияние на функцию цели. Учтены ограничения по прочности стенки на сдвиг и по устойчивости стенки по общей форме. Показано, что введение в разрешающее уравнение условий прочности на сдвиг и устойчивость стенки указывает на нижний предел значения параметра проектирования. Ограничение неактивно з области допускаемых решений. Рассмотрены также значения минимальной высоты по условию непревышения допустимого прогиба с учетом деформаций сдвига тонкой стенки.

Показаны области допускаемых решений. Численные исследования проведены для балочных конструкций с волнистой стенкой, в качестве ограничения используются неравенства/равенства условий обеспечения несущей способности в соответствии с ДБН В.2.6-198. Получены оптимальные значения высоты балки по критерии минимума массы в диапазоне используемых пролетов и нагрузок. Показаны значения пролетов и нагрузок для балок с волнистыми стенками в области оптимальных параметров и технологических ограничений. Отмечена необходимость проведения дальнейших и следований с целью поиска конструктивных решений, снижающих значения конструктивных коэффициентов, а также с детальным учетом специфических эффектов работы, как локальные напряжения, несовершенства и реальных условий эксплуатации.
\end{abstract}

Ключевые слова: стальная балка, гофрированная стенка, оптимальная высота, ограничения проектирования.

Стаття надійшла до редакції 4.09.2020 